\title{
PERANAN WANITA TANI-NELAYAN DALAM MASYARAKAT NELAYAN PERAIRAN UMUM DANAU PENGEMBUNG, KABUPATEN KAPUAS HULU
}

\author{
Eko Dewantoro"), Purnamawati "') dan Djamaluddin S'.',
}

\begin{abstract}
ABSTRAK
Penelitian ini dilakukan di perkampungan nelayan Danau Pengembung, Kecamatan Selimbau, Kabupaten Kapuas Hulu. Penelitian bertujuan untuk mendapatkan informasi tentang peranan wanita tani-nelayan dalam masyarakat nelayan perairan umum di Danau Pengembung, yang meliputi keterlibatan wanita dalam usaha tani nelayan dan peranan wanita dalam pengambilan keputusan. Metode yang digunakan adalah pemahaman pedesaan secara partisipatif (PRA) dengan melibatkan 33 orang pria/wanita nelayan. Data yang dikumpulkan meliputi data primer dan data sekunder. Data di analisis menggunakan metode Harvard dan dibahas secara deskriptif. Hasil penelitian menunjukkan bahwa, peran wanita dalam masyarakat nelayan perairan umum di Danau Pengembung terlihat pada bidang produksi dan panen, pasca panen, dan penjualan hasil perikanan. Pengambilan keputusan dalam kegiatan usaha tani-nelayan secara umum dilakukan secara bersama-sama antara pria dan wanita, tetapi dalam pemasaran hasil wanita tani-nelayan cukup berperan. Demikian pula dalam pemanfaatan uang keperluan sehari-hari peranan istri terlihat lebih dominan. Untuk meningkatkan peranan wanita dalam sistem usaha tani-nelayan perlu dilakukan pelatihan dan penyuluhan.
\end{abstract}

ABSTRACT: The roles of women in the inland fishing community of Pengembung Lake, Kapuas Hulu District. By: Eko Dewantoro, Purnamawati and Djamaluddin

This research was conducted at the Pengembung Lake fisheries society, Selimbau Subdistrict Kapuas Hulu District. The research aimed for obtaining informations related to women's roles on decision making and activities in inland fishing community. Participatory Rural Appraisal (PRA) was used as research method with 33 fishers. Primary and secondary data were collected in this research. Harvard method was used to analyze the data and the results were also briefly discussed descriptively. The results showed that women had roles at production, harvesting, posharvesting and marketing activities. More over, decision making process in fisheries activities are involved both men and women; however the role of women in marketing are significant women had more roles in managing daily house hold budget. In order to increase the role of women in the fisheries activities, a sort of training and extension should be conducted.

KEYWORDS : fish-farmer women, Pengembung Lake

\section{PENDAHULUAN}

Sebagian besar penduduk Indonesia (78\%) tinggal di pedesaan, sehingga kehidupan masyarakat erat kaitannya dengan bidang pertanian. Oleh karena itu, sektor pertanian memberikan sumbangan yang sangat penting bagi perekonomian Indonesia. Dalam upaya mengembangkan pertanian di masa datang, selain ditentukan oleh faktor alam dan teknologi, juga tidak terlepas dari ketersediaan sumberdaya manusia. Faktor alam tidak dapat dirubah, sehingga kualitas sumberdaya manusia merupakan titik sentral yang harus diperhatikan.

Sampai saat ini, sektor pertanian menyerap tenaga kerja baik pria maupun wanita yang cukup banyak.
Peran wanita di Asia dalam bidang pertanian cukup besar karena lebih dari 50\% kegiatan pertanian dilakukan oleh wanita (Nancy et al., 1997). Selain itu, sumberdaya utama dalam pembangunan di sektor pertanian adalah petani/nelayan dan keluarga. Oleh karena itu, keberhasilan pembangunan pertanian sangat ditentukan oleh peran aktif petani-nelayan berserta anggota keluarganya (termasuk wanita tani). Sebagai anggota keluarga tani, wanita tani dituntut untuk lebih menguasai pengetahuan dan ketrampilan terutama di bidang usaha tani (Wijayanto, 1997).

Agar aspirasi, kepentingan dan peranan wanita dapat terintegrasi dalam kebijaksanaan dan program, perlu digali permasalahan pokok yang ada dalam hubungan (interrelationship) antara pria dan wanita di

\footnotetext{
") Staf Peneliti pada Balai Pengkajian Teknologi Pertanian, Kalimantan Barat

*) Staf Pengajar pada Politeknik Negeri Pontianak

“..) Staf Peneliti pada Balai Pengkajian Teknologi Pertanian, Sulawesi Selatan
} 
berbagai bidang, sesuai keputusan Menteri Negara Urusan Peranan Wanita Nomor 06/Kep/MenUPW/III/ 1995 tentang pedoman penyusunan Profil Kedudukan dan Peranan Wanita Indonesia Tingkat Daerah (Lumangkun et al., 2000). Khususnya di bidang pertanian. Permasalahan pokok itu dapat ditemukenali dengan menggunakan analisis gender.

Dari pemantauan dan berdasarkan kacamata fakta yang ada menunjukkan bahwa wanita sangat berperan di bidang usaha tani, baik usaha tani tanaman pangan, peternakan, perkebunan, maupun perikanan. Pada usaha tani perikanan, mereka berperan dari proses produksi, panen hingga pasca panen. Namun, kebijakan pembangunan pertanian yang diambil, tidak jarang mengabaikan peran mereka. Hal ini mungkin disebabkan oleh kurangnya informasi yang dimiliki atau kurangnya pemahaman tentang hal tersebut.

Berdasarkan kasus masyarakat nelayan di Dusun Pengembung menunjukkan bahwa, pembuatan alatalat tangkap ikan, pembuatan keramba, pembuatan perahu untuk menangkap ikan dilakukan oleh kaum pria (suami). Walaupun demikian kaum wanita lebih banyak alokasi waktu kerjanya dari kaum pria dalam hal memberi makan ikan. Sedangkan dari segi pengolahan seperti membersihkan ikan sebelum diolah, penggaraman ikan, pengasapan ikan, penjemuran ikan, dan mencari kayu bakar untuk pengasapan ikan lebih banyak dilakukan oleh kaum wanita (istri). Pada kegiatan pengangkutan dan pemasaran hasil banyak dilakukan oleh kaum pria (suami).

Uraian di atas menunjukkan bahwa pria dan wanita dalam melakukan kegiatan usaha tani mempunyai peran masing-masing dengan pola tertentu. Pola pembagian kerja antara pria dan wanita dikenal dengan istilah pembagian kerja berdasarkan analisis gender. Untuk lebih mamahami peranan wanita tani dapat didekati dengan analisis gender pula. Dengan analisis ini dapat diketahui peranan masing-masing anggota rumah tangga, baik dalam proses produksi, panen maupun pasca panen (Wijayanto, 1997).

\section{Maksud dan Tujuan Penelitian}

Penyusunan Peranan Wanita Tani-Nelayan dalam masyarakat nelayan perairan umum Danau Pengembung melalui analisis gender dimaksudkan untuk memperoleh data dan informasi serta tergalinya permasalahan gender, yang diperlukan oleh para perumus kebijakan. Hal ini perlu untuk pengambilan keputusan dan perencanaan dalam mengintegrasikan aspirasi, kepentingan serta peranan wanita dan pria secara selaras, serasi dan seimbang dalam proses pembangunan di segala bidang, termasuk kehidupan berkeluarga, bermasyarakat, berbangsa dan bernegara.

Penelitian ini bertujuan untuk mempelajari dan mengetahui peranan wanita dalam usaha tani-nelayan, baik pada kegiatan produktif maupun dalam mengambil keputusan

\section{METODE}

Penelitian ini mengangkat peranan wanita tani dalam sistem usaha tani-nelayan di Danau Pengembung (Kawasan Danau Sentarum), Kecamatan Selimbau, Kabupaten Kapuas Hulu, Kalimantan Barat. Pemilihan lokasi ini dipilih secara sengaja dengan pertimbangan bahwa relatif dekat untuk dijangkau dibandingkan perkampungan nelayan lainnya dan termasuk salah satu daerah penghasil ikan perairan umum di Kabupaten Kapuas Hulu yang hampir seluruh penduduknya berprofesi sebagai nelayan. Dengan demikian, informasi mengenai peranan wanita tani dalam sistem usaha tani-nelayan dapat diperoleh dengan lebih mudah dan merupakan gambaran peranan wanita pada umumnya di perkampungan nelayan perairan umum Kabupaten Kapuas Hulu.

Data yang digunakan pada penelitian ini terdiri dari data primer dan data sekunder. Data primer diperoleh dengan metode pemahaman pedesaan secara partisipatif (PRA) (Chambers, 1996). Diskusi yang dilakukan melibatkan ketua nelayan Pengembung, nelayan, wanita tani-nelayan, dan masyarakat yang memiliki profesi utama yang lain disamping sebagai nelayan. Data sekunder diperoleh dari BIPP Kabupaten Kapuas Hulu dan Cabang Dinas Perikanan Kabupaten Kapuas Hulu. Data yang diambil terdiri dari karakteristik wilayah, penduduk dan aktivitas harian. Data yang diperoleh ditabulasikan dalam bentuk tabel dan dianalisis dengan metode Harvard.

Analisis Harvard merupakan salah satu metode analisis penelitian gender. Metode ini mempunyai 3 komponen utama yaitu profil kegiatan, profil akses dan kontrol, dan analisis faktor yang mempengaruhi akses-kontrol. Untuk mengetahui peranan wanita dalam pengambilan keputusan dapat digunakan profil akses-kontrol (Purnamawati \& Lumangkun, 2000).

Pada metode tersebut, keputusan orang tua lakilaki (dalam persen) terhadap suatu aktivitas merupakan perbandingan antara jumlah responden orang tua laki-laki yang setuju dengan jumlah responden seluruhnya. Cara yang sama juga dapat digunakan untuk keputusan orang tua wanita, anak laki-laki dan anak wanita. 
Akses keluarga pada suatu aktivitas dapat dikelompokkan menjadi dua yaitu orang tua dan anak. Akses orang tua merupakan selisih dari analisis orang tua laki-laki dan wanita. Bila selisih tersebut bertanda (+) berarti pengambilan keputusan didominasi orang tua laki-laki, sebaliknya bila bertanda (-) berarti pengambilan keputusan di dominasi orang tua wanita. Besarnya akses anak dapat dicari dengan metode yang sama dengan pengukuran akses orang tua. Hasil analisis ini selanjutnya akan dibahas secara deskriptif induktif, sehingga dapat menggambarkan peranan wanita tani nelayan Danau Pengembung secara umum.

\section{HASIL DAN BAHASAN}

\section{Karakteristik Wilayah}

Pengembung merupakan salah satu danau yang ada di Kecamatan Selimbau Kabupaten Kapuas Hulu. Di danau ini terdapat perkampungan nelayan yang dicirikan dengan bentuk dusun tipe memanjang sesuai alur danau. Transportasi dari Pengembung ke Kecamatan Selimbau ataupun ke kecamatan lain tidak begitu lancar, karena transportasi yang ada hanya berupa angkutan air yang tidak setiap saat ada (jumlahnya masih terbatas). Transportasi ke Pengembung hanya berupa sampan motor cepat, sampan motor panjang (sampan motor nelayan) dan motor bandung (motor air berbentuk seperti rumah). Sedangkan lamanya waktu yang ditempuh dari Nanga Suhaid ke Pengembung adalah 3,5 jam jika menggunakan sampan motor nelayan, kalau menggunakan sampan motor cepat waktu yang ditempuh adalah 2 jam.

Jalan di kampung nelayan tersebut pada dasarnya tanah, tapi karena daerah tersebut termasuk rendah, dan dapat digenangi air dan menjadi banjir pada saat air danau naik, maka dibuat jalan berupa jembatanjembatan kayu dengan ketinggian \pm 3 meter dari permukaan tanah. Begitu pula halnya rumah-rumah penduduk dan bangunan-bangunan lain yang ada di daratan.

Beberapa sarana penunjang seperti warung-warung telah ada di daerah tersebut. Tetapi warung-warung umumnya hanya menjual bahan konsumsi, sehingga untuk memenuhi kebutuhan sarana produksi sebagian besar masyarakat membeli pada kios-kios yang ada di Kecamatan Selimbau, Semitau dan Nanga Suhaid bahkan ada yang membeli sampai ke Sintang. Sedangkan sarana penunjang lainnya yang ada yaitu masjid, Puskesmas pembantu dan gedung Sekolah Dasar (SD) yang merupakan SD cabang Sekulat.

Di Pengembung terdapat satu kelompok nelayan dengan 61 anggota, nama kelompok tersebut adalah
"Kelompok Petani--Nelayan Pengembung". Kelompok tani-nelayan ini dipimpin oleh seorang ketua nelayan. Ketua nelayan di Pengembung mempunyai fungsi ganda. Fungsi pertama sebagai pemimpin bagi kelompok nelayan dan yang kedua juga berperan sebagai kepala kampung.

\section{Profil Nelayan Danau Pengembung Kabupaten Kapuas Hulu}

Penduduk Pengembung terdiri dari $61 \mathrm{KK}$ (merupakan penduduk tetap) dan 5-10 KK merupakan penduduk nomaden yang datang hanya pada saat musim ikan. Penduduk tetap biasanya memiliki rumah sendiri di darat, sedangkan penduduk nomaden membuat rumah diatas rakit (lanting). Seluruh penduduk pengembung (100\%) adalah dari suku Melayu dan beragama Islam

Mata pencaharian utama penduduk Pengembung adalah sebagai nelayan dan pembudidaya ikan dalam keramba (ikan toman, ikan betutu dan ikan belida). Mata pencaharian lain adalah berdagang, guru, pengolah ikan asin baik dari hasil tangkapan sendiri maupun hasil tangkapan nelayan setempat, dan pengolah ikan asap (pada musim tertentu saja), serta sebagai penggergaji kayu

Sampai dengan tahun 2001 jumlah penduduk Dusun Pengembung tercatat 246 jiwa yang terdiri dari 50,41 persen (124 jiwa) diantaranya adalah wanita, dan sisanya 49,59 persen (122 jiwa) adalah pria. Berdasarkan pada pembagian kelompok usia produktif (Tabel 1), sebagian besar penduduk termasuk dalam kelompok usia produktif, yakni pada umur 16 - 50 tahun sebanyak 147 jiwa yang terdiri dari 72 jiwa wanita dan 75 jiwa pria. Dengan melihat komposisi di atas berarti tenaga wanita di Dusun Pengembung ini mempunyai potensi untuk diberdayakan.

Keterlibatan tenaga kerja wanita dalam sistem usaha tani-nelayan dipengaruhi oleh sumberdaya wanita itu sendiri. Menurut Sajogyo (1984) dalam Lestari et al. (1997), wanita Indonesia di pedesaan bersama kaum pria merupakan sumberdaya manusia yang memiliki partisipasi cukup nyata khususnya dalam hal pemenuhan fungsi ekonomi keluarga dan rumah tangga. Hal ini dipertegas oleh Dahlia (1997), bahwa salah satu aspek sumberdaya pembangunan yang potensial apabila diikutsertakan secara aktif dalam pelaksanaan pembangunan adalah wanita. Keberadaan wanita secara nasional dari segi kuantitas lebih banyak dibandingkan dengan pria walaupun secara regional (ditingkat propinsi) jumlah pria ada yang lebih besar dibanding wanita. Di samping itu, kaum wanita mempunyai peranan yang penting di dalam kehidupan bermasyarakat dan bernegara, dimana peranan yang dimaksud tidak saja untuk 
dipimpin tetapi juga untuk memimpin. Sumberdaya wanita itu sendiri berkaitan dengan mata pencaharian kepala keluarga, umur dan tingkat pendidikan serta jumlah anak.

\section{Profil Wanita Tani Nelayan}

Dari Tabel 1 dapat dijelaskan bahwa secara umum nelayan wanita di Dusun Pengembung Kabupaten Kapuas Hulu didominasi oleh kelompok umur 16-50 tahun $(29,27 \%)$. Untuk umur $0-15$ dan $>50$ tahun persentasenya tidak jauh berbeda yaitu berkisar $10,16 \%$ sampai $10,98 \%$. Berdasarkan persentase ini masih banyak nelayan wanita yang tergolong usia produktif. Namun dari segi pendidikan, sebagian besar pendidikan istri hanya sampai kelas 3 SD bahkan ada yang belum merasakan pendidikan sama sekali. Dengan kualitas seperti ini, perlu adanya upaya untuk meningkatkan pengetahuan dan ketrampilan mereka melalui pendidikan non formal (penyuluhan). Menurut Sulaeman (1997), pembangunan sumber daya manusia dan alih teknologi merupakan misi utama penyuluhan, maka institusi penyuluhan berada pada posisi yang sangat strategis dalam upaya pemberdayaan wanita. Dan berbagai pendekatan penyuluhan dapat digunakan secara efektif untuk menjangkau kelompok didik wanita di pedesaan, tanpa harus menganggu tatanan sosial dan budaya yang ada. Pendekatan apapun yang digunakan, seyogyanya aspek gender merupakan komponen yang telah menyatu dengan komponen lainnya dalam proses penyusunan program penyuluhan.

\section{Profil Nelayan Pria}

Seperti halnya dengan profil nelayan wanita, nelayan pria (Tabel 1) pada umumnya didominasi kelompok umur $16-50$ tahun $(30,49 \%)$. Persentase terendah berada pada kelompok umur 0-15 tahun $(9,34 \%)$ dan $>50$ tahun $(9,76 \%)$. Berarti sebagian besar jumlah nelayan pria berada pada usia produktif dari umur 16 - 50 tahun dan masih cukup banyak pria usia 50 tahun keatas yang masih aktif bekerja sebagai nelayan. Berdasarkan tingkat pendidikan sebagian besar nelayan pria hanya tamatan SD saja. Berarti permasalahan ini sama dengan permasalahan yang terjadi pada kelompok wanita nelayan. Maka perlu adanya upaya untuk meningkatkan pengetahuan dan ketrampilan mereka melalui pendidikan non formal (penyuluhan)

\section{Keterlibatan Wanita dalam Kegiatan Usaha Tani Nelayan}

Jadwal kegiatan sehari-hari menggambarkan aktifitas harian. Keterlibatan wanita tani-nelayan dalam kegiatan usaha tani-nelayan di Danau Pengembung dapat dilihat dari aktivitas harian yang disajikan pada Tabel 2. Wanita tani-nelayan dalam rumah tangga mempunyai peranan yang cukup penting. Mereka tidak saja sebagai ibu rumah tangga biasa, tetapi juga berperan dalam kegiatan usaha taninelayan. Fenomena ini telah diuraikan oleh Dahlia (1997) bahwa pada beberapa negara ditemukan $60 \%$ sampai dengan $80 \%$ dari jumlah penduduk wanita merupakan tenaga kerja di sektor pertanian. Selain itu $75 \%$ sampai dengan $90 \%$ dari jumlah keseluruhan penduduk bergantung pada sektor pertanian, yang berarti bahwa dalam banyak kasus proporsi tertinggi dari penduduk wanita terlibat langsung dalam kegiatan pertanian.

Pada Tabel 2 dan 3 dapat dilihat aktifitas harian masyarakat Danau Pengembung. Dari aktivitas harian ini dapat diketahui pelaku pekerjaan di rumah, dan pekerjaan-pekerjaan yang bersifat produktif lainnya sehingga ketidakadilan gender pada suatu komunitas akan terlihat. Dari kedua tabel tersebut tergambar bahwa kaum wanita Dusun Pengembung lebih banyak bekerja dari pada kaum pria. Besarnya curahan kerja

Tabel 1. Jumlah penduduk menurut kelompok umur dan jenis kelamin di Dusun Pengembung, 2001 Table 1. The number of inhabitants of Pengembung Village according to the age and sexs groups

\begin{tabular}{ccccccc}
\hline $\begin{array}{c}\text { Kelompok umur } \\
\text { (Tahun)/Groups of ages } \\
\text { (Years) }\end{array}$ & \multicolumn{2}{c}{ Pria/Men } & \multicolumn{2}{c}{ Wanita/Women } & \multicolumn{2}{c}{ Total/Total Number } \\
\cline { 2 - 7 } & $\begin{array}{c}\text { Jumlah/ } \\
\text { Number }\end{array}$ & $\mathbf{( \% )}$ & $\begin{array}{c}\text { Jumlah/ } \\
\text { Number }\end{array}$ & $\mathbf{( \% )}$ & $\begin{array}{c}\text { Jumlah/ } \\
\text { Number }\end{array}$ & $(\%)$ \\
\hline $0-15$ & 23 & 9.34 & 25 & 10.16 & 48 & 19.51 \\
$16-50$ & 75 & 30.49 & 72 & 29.27 & 147 & 59.76 \\
$>50$ & 24 & 9.76 & 27 & 10.98 & 51 & 20.73 \\
\hline Jumlah/Total Number & 122 & 49.59 & 124 & 50.41 & 246 & 100 \\
\hline
\end{tabular}

Sumber/Source: Profil Dusun Pengembung, Kec. Selimbau (2001)/Profiles of Pengembung Village, Selimbau Subdistrict (2001) 
Tabel 2. Jadwal aktivitas harian wanita tani di perkampungan nelayan Danau Pengembung Table 2. The schedule of daily activities of women in fish farmer village of Pengembung Lake

\begin{tabular}{|c|c|}
\hline $\begin{array}{l}\text { Waktu/Hours } \\
\text { (WIB) }\end{array}$ & Kegiatan/Activities \\
\hline $04.30-05.00$ & $\begin{array}{l}\text { Bangun, sholat subuh, masak, bersihkan rumah, mandi/Getting up, praying, } \\
\text { cooking, cleaning the house, taking a bath }\end{array}$ \\
\hline $05.00-05.30$ & $\begin{array}{l}\text { Menyiapkan sarapan, menyiapkan perbekalan, mencuci piring/Preparing } \\
\text { breakfast, preparing working supplies, washing dishes }\end{array}$ \\
\hline $05.30-11.00$ & Ke danau untuk menangkap ikan/Going to lake to catch fish \\
\hline $11.00-15.00$ & $\begin{array}{l}\text { Memberi makan ikan, membersihkan ikan hasil tangkapan, mandi, } \\
\text { memasak, makan, mencuci piring, sholat zuhur, istirahat/Feeding the fish, } \\
\text { cleaning the catch fish, taking a bath, cooking, having a lunch, washing } \\
\text { dishes, praying, taking a nap }\end{array}$ \\
\hline $15.00-16.30$ & Mencari kayu bakar/Looking for burning woods \\
\hline $16.30-17.30$ & Mandi, sholat ashar, memasak/Taking a bath, praying, cooking \\
\hline $17.30-18.30$ & Sholat magrib, makan malam/Praying, having a dinner \\
\hline $18.30-22.00$ & $\begin{array}{l}\text { Sholat isya, santai (nonton TV dan nonton VCD)/Praying, relaxing (watching } \\
T V \text { or VCD film) }\end{array}$ \\
\hline $22.00-04.30$ & Tidur/Going to bed \\
\hline
\end{tabular}

Sumber/Source: Data primer, diolah/Primary data, processed

Tabel 3. Jadwal aktivitas harian nelayan pria di perkampungan nelayan Danau Pengembung, 2001

Table 3. The schedule of daily activities of fishermen in fish farming village of Pengembung Lake, 2001

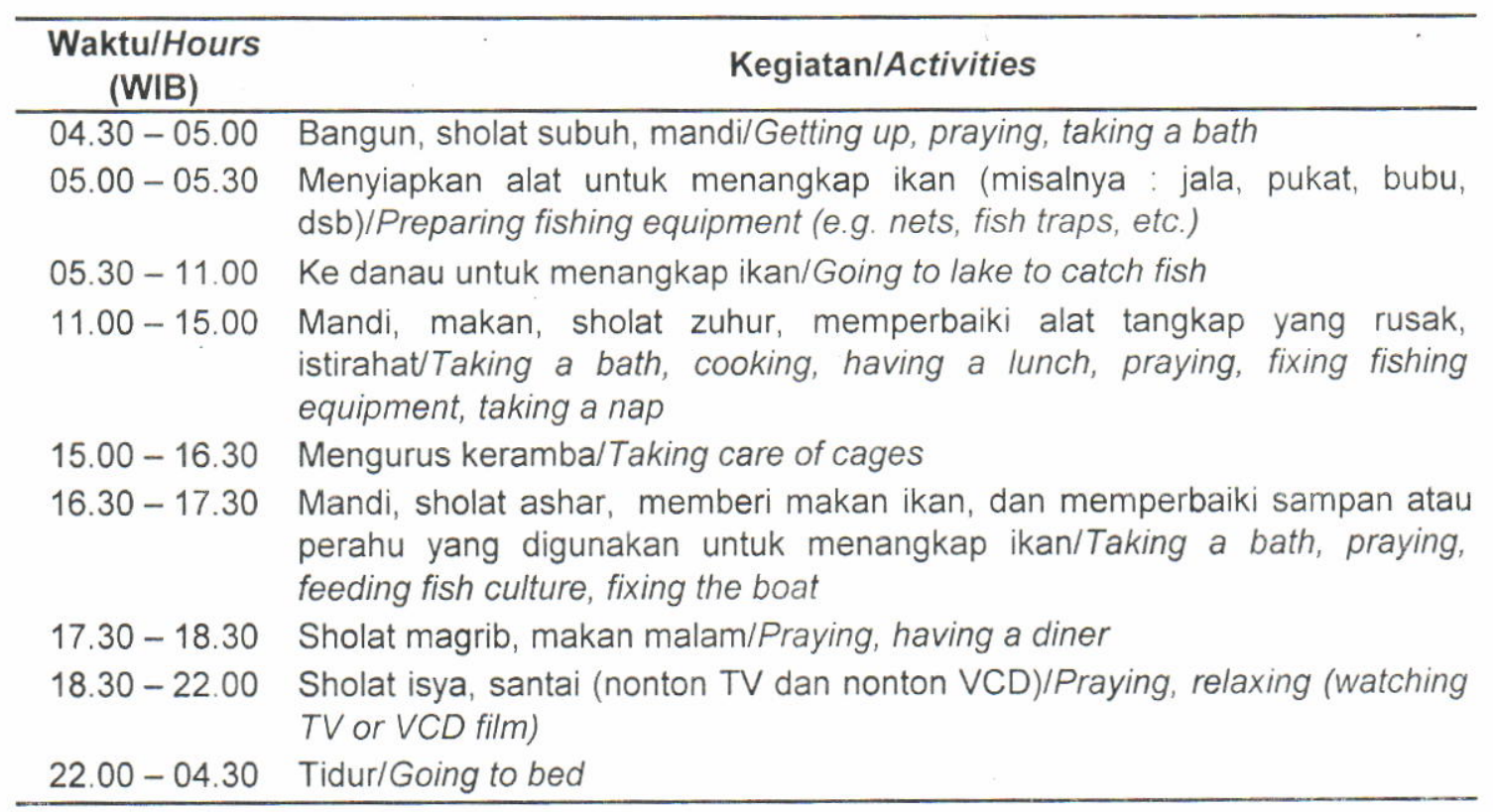

Sumber/Source: Data primer, diolah/Primary data, processed

istri di kegiatan usaha tani-nelayan ini logis bila dikaitkan dengan fungsinya sebagai ibu rumah tangga (mengurus rumah, anak dan anggota keluarga lainnya). Karena pada umumnya aktifitas ini dapat dilakukan di dekat rumah. Pada kegiatan tersebut, seorang istri selain mendapatkan tambahan penghasilan, juga dapat melakukan fungsinya sebagai ibu rumah tangga. Menurut Baharsjah (1997), wanita cukup banyak memberikan konstribusi pada kegiatan produksi dan kegiatan lain yang menambah 
penghasilan keluarga, karena itu kaum wanita kadang-kadang terlibat dalam pekerjaan yang biasa dilakukan oleh pria, sehingga tidak hanya sekedar berperan sebagai anggota rumah tangga. Menurut Suwondo (1990) dalam Noor dan Us (1995), wanita tani di pedesaan mengemban tugas ganda, di samping tanggung jawab utama dan perannya dalam membina keluarga sehat sejahtera, juga memberi motivasi pada generasi (remaja) yang sehat dalam rangka pembangunan manusia seutuhnya. Selanjutnya Siwi (1990) dalam Heruwati et al (1998) menyatakan bahwa untuk bidang perikanan wanita telah menyumbangkan 50\%-75\% tenaganya pada kegiatan tersebut dan tidak sedikit yang memberikan penghasilan tambahan dan sumbangan yang cukup berarti secara ekonomi. Kondisi seperti inilah yang umumnya ditemui pada perkampungan nelayan di Danau Pengembung

\section{Peranan Wanita Tani-Nelayan Dalam Pengambilan Keputusan.}

Pengambilan keputusan usaha tani-nelayan adalah keterlibatan istri, suami atau keduanya dalam memutuskan sesuatu di bidang usaha tani-nelayan, sebelum kegiatan usaha tani-nelayan tersebut dilaksanakan. Hal ini dipertegas oleh Lestari et al (1997), yang menyatakan bahwa keluarga merupakan unit pengambilan keputusan yang menentukan beberapa orang dan siapa diantara anggota keluarga yang harus bekerja dan berapa jam setiap hari orang tersebut perlu bekerja, mengurus rumah tangga dan meneruskan sekolah. Pengambilan keputusan tersebut dapat dilihat pada Tabel 4

Secara umum, dalam kegiatan usaha tani-nelayan diputuskan secara bersama-sama. Namun untuk aktivitas pengolahan ikan, penjualan hasil dan pengelolaan keuangan istri (wanita tani-nelayan) lebih berperan. Satu hal yang cukup menarik untuk disoroti adalah dalam hal pemasaran hasil, para wanita taninelayan cenderung memilih memasarkan hasil-hasil budidaya ikan dan ikan hasil olahan ke luar daerah tempat tinggal (misalnya dibawa ke perbatasan Serawak-Lanjak, Putussibau, Sintang maupun daerah-daerah lain), dengan membawanya langsung tanpa harus menunggu pedagang-pedagang dari luar datang ke daerah tersebut untuk membelinya. Menurut

Tabel 4. Penentuan keputusan oleh keluarga tani di Danau Pengembung, Kecamatan Selimbau, (dalam $\%), 2001$

Table 4. Decision making by fishermen families in Pengembung Village, Selimbau Subdistrict (in \%), 2001

\begin{tabular}{|c|c|c|c|c|c|c|c|}
\hline \multirow[b]{2}{*}{ No } & \multirow[b]{2}{*}{$\begin{array}{l}\text { Jenis ke putusan/ } \\
\text { Kinds of decisions }\end{array}$} & \multicolumn{2}{|c|}{$\begin{array}{l}\text { Orang tual } \\
\text { Parents }\end{array}$} & \multicolumn{2}{|c|}{$\begin{array}{l}\text { Anakl } \\
\text { Children }\end{array}$} & \multicolumn{2}{|c|}{$\begin{array}{l}\text { Keputusan/ } \\
\text { Decisions }\end{array}$} \\
\hline & & $\begin{array}{l}\text { Bapakl } \\
\text { Father } \\
\text { (1) }\end{array}$ & $\begin{array}{l}\text { Ibul } \\
\text { Mother } \\
(2)\end{array}$ & $\begin{array}{l}\text { Pria I } \\
\text { Sons } \\
\text { (3) }\end{array}$ & $\begin{array}{l}\text { Wanital } \\
\text { Daugther } \\
\text { (4) }\end{array}$ & $\begin{array}{l}\text { Orang tual } \\
\text { Parents } \\
\text { (1)-(2) }\end{array}$ & $\begin{array}{l}\text { Anak/ } \\
\text { Child } \\
(3)-(4)\end{array}$ \\
\hline 1 & $\begin{array}{l}\text { Menentukan alat tangkap yang akan } \\
\text { digunakan/Determining of fishing equipment } \\
\text { to be used }\end{array}$ & 42.4 & 0 & 9.1 & 6.1 & +42.4 & 3 \\
\hline 2 & $\begin{array}{l}\text { Menentukan waktu penangkapan } \\
\text { ikan/Determining the time of catching fish }\end{array}$ & 42.4 & 42.4 & 6.1 & 6.1 & 0 & 0 \\
\hline 3 & $\begin{array}{l}\text { Menentukan ikan yang akan diolah, waktu } \\
\text { pengolahan dan aktifitas } \\
\text { pengolahan/Determining the fish, time and } \\
\text { activities of fish processing }\end{array}$ & 18.2 & 42.4 & 0 & 6.1 & -24.2 & -6.1 \\
\hline 4 & $\begin{array}{l}\text { Perbaikan dan persiapan keramba dan panen } \\
\text { ikan/Fixing and preparing the fish traps and } \\
\text { harvesting }\end{array}$ & 42.4 & 0 & 9.1 & 0 & 42.4 & 9.1 \\
\hline 5 & Memberi makan ikan/Feding the fish culture & 42.4 & 42.4 & 6.1 & 3 & 0 & 3.1 \\
\hline 6 & $\begin{array}{l}\text { Ikut dalam penyuluhan/Participating in } \\
\text { trainings or extentions }\end{array}$ & 21.2 & 12.2 & 6.1 & 0 & 9.1 & 6.1 \\
\hline 7 & $\begin{array}{l}\text { Pemasaran hasil perikanan/Marketing the } \\
\text { fish }\end{array}$ & 27.3 & 42.4 & 3 & 6.1 & -15.1 & -3.1 \\
\hline 8 & Pengelolaan keuangan/Controlling the money & 21.2 & 42.4 & 3 & 6.1 & -21.2 & -3.1 \\
\hline
\end{tabular}

Keterangan/Note: (+) Pria dominan, (-) wanita dominan dan (0) pria dan wanita berimbang.

(+) Men's domination, (-) women's domination, and (0) men and women sharing domination 
Baharsjah (1997), melibatkan wanita secara penuh dalam proses pengambilan keputusan dan berpartisipasi sesuai kodratnya, akan mengoptimalkan upaya keluarga dalam memanfaatkan aset produktif yang dimilikinya. Secara langsung hal ini akan menunjang upaya peningkatan produktivitas pertanian di pedesaan dan pada akhirnya akan meningkatkan kesejahteraan keluarga dan ketahanan nasional sebagai suatu bangsa ditengah kompetisi lingkungan global. Hal ini dipertegas oleh Nancy et al. (1997), bahwa meningkatnya peluang bekerja bagi wanita pedesaan akan meningkatkan potensi wanita untuk mengambil keputusan.

Dalam pemanfaatan uang hasil penjualan untuk keperluan sehari-hari umumnya diserahkan kepada wanita, kecuali untuk keperluan yang membutuhkan dana besar diputuskan secara bersama-sama.

\section{KESIMPULAN DAN SARAN}

Peranan wanita tani-nelayan melalui aktivitas di bidang produksi, panen dan pasca panen, serta penjualan hasil perikanan yang dilaksanakan di dalam maupun di luar rumah memberikan konstribusi secara langsung berupa material yang membantu dalam pengelolaan dan pengeluaran rumah tangga yang pada gilirannya menentukan kesejahteraan keluarga. Pengambilan keputusan dalam kegiatan usaha taninelayan secara umum dilakukan secara bersamasama antara pria dan wanita, tetapi dalam pemasaran hasil wanita tani-nelayan cukup berperan, demikian pula dalam pemanfaatan uang keperluan sehari-hari peranan istri lebih dominan.

Untuk meningkatkan peranan wanita dalam sistem usaha tani-nelayan perlu dilibatkan wanita dalam pelatihan dan penyuluhan terutama mengenai penanganan pasca panen. Analisis lanjutan tentang curahan tenaga kerja dan jenis-jenis usaha produktif yang mungkin dapat dilakukan oleh para wanita taninelayan diperlukan, sehingga dapat meningkatkan pendapatan keluarga.

\section{DAFTAR PUSTAKA}

Baharsjah, J. S. 1997. Potensi permasalahan dan alternatif pendekatan pemberdayaan sumberdaya wanita memasuki industrialisasi pedesaan. Prosiding Lokakarya Pemberdayaan Sumberdaya Wanita Melalui Pengembangan Agribisnis di Pedesaan. Perhimpunan Agronomi Indonesia (PERAGI) Bekerjasama dengan Kantor Menteri Negara UPW dan Badan Agribisnis - Deptan. p. 136

Chambers, R. 1996. PRA: Participatory Rural AppraisalMemahami Desa Secara Partisipatif. Kanisius Yogyakarta. p. 1-114.
Dahlia, D. 1997. Partisipasi wanita di bidang pertanian. Prosiding Lokakarya Pemberdayaan Sumberdaya Wanita Melalui Pengembangan Agribisnis di Pedesaan. Perhimpunan Agronomi Indonesia (PERAGI) Bekerjasama dengan Kantor Menteri Negara UPW dan Badan Agribisnis - Deptan. p. 187194

Heruwati, E.S., Wijono, A. dan Murniyati. 1998. Peranan Wanita Nelayan Dalam Kegiatan Perikanan. Warta Penelitian Perikanan Indonesia (4) : 16-22.

Lestari, E. R., Santoso I. dan Sulastri. R. D. 1997. Konstribusi Wanita dalam Agribisnis Gula Semut di Kabupaten Blitar, Prop. Jawa Timur. Jurnal Penelitian IImu-IImu Sosial (Social Sciences), 9 (1) : 47-53.

Lumangkun, A., Purnamawati, Yusuf, A. dan Harniati. 2000. Laporan Hasil Profil Kedudukan dan Peranan Wanita Tani di Kalimantan Barat. Kerjasama Lembaga Penelitian Universitas Tanjung Pura dengan Loka Pengkajian Teknologi Pertanian Pontianak. Loka Pengkajian Teknologi Pertanian Pontianak. Badan Penelitian dan Pengembangan Pertanian Departemen Pertanian

Nancy, C, Gunawan, A. Oekeley, H.B. dan Conroy, C 1997. Peran wanita tani dalam kegiatan dan pengambilan keputusan usaha tani karet serta konstribusinya terhadap pendapatan keluarga. Prosiding Lokakarya Pemberdayaan Sumberdaya Wanita Melalui Pengembangan Agribisnis di Pedesaan. Perhimpunan Agronomi Indonesia (PERAGI) Bekerjasama dengan Kantor Menteri Negara UPW dan Badan Agribisnis - Deptan. p. 139155 .

Noor, M. dan Us, K.H. 1995. Konstribusi kaum wanita dalam pengembangan sistem usaha tani mina padi di Desa Nanggerang, Binong, Kabupaten Subang. J. Penel. Perik. Indonesia, I (4) : 61-70.

Profil Dusun Pengembung Kecamatan Selimbau Kabupaten Kapuas Hulu.

Purnamawati dan Lumangkun, A. 2000. Lokakarya Sosialisasi dan Inkorporasi Saga Pada Penelitian dan Pengkajian Teknologi Pertanian. Pontianak 1823 September 2000

Sulaeman, F. 1997. Pendekatan Penyuluhan dalam Pemberdayaan Sumberdaya Perempuan Melalui Pengembangan Agribisnis di Pedesaan. Prosiding Lokakarya Pemberdayaan Sumberdaya Wanita Melalui Pengembangan Agribisnis di Pedesaan. Perhimpunan Agronomi Indonesia (PERAGI) Bekerjasama dengan Kantor Menteri Negara UPW dan Badan Agribisnis - Deptan. p. 207-224.

Wijayanto, B. 1997. Peranan wanita tani dalam sistim usaha tani padi (Studi Kasus di Desa Rejomulyo Kab. Lampung Tengah). Prosiding Lokakarya Pemberdayaan Sumberdaya Wanita Melalui Pengembangan Agribisnis di Pedesaan. Perhimpunan Agronomi Indonesia (PERAGI) Bekerjasama dengan Kantor Menteri Negara UPW dan Badan Agribisnis-Deptan. p. 165 - 172 
